\title{
STUDI KOMUNITAS BAKTERI PADA SISTEM RESIRKULASI PADA BUDIDAYA LELE DUMBO (Clarias gariepinus)
}

\section{Study of Bacteria Community in the Recirculation System of Catfish (Clarias gariepinus) Cultivation}

\author{
Wahyu Isroni ${ }^{*}$, Dyah Setyawati ${ }^{2}$ dan Nurul Maulida ${ }^{3}$ \\ ${ }^{1}$ Fakultas Perikanan dan Kelautan, Universitas Airlangga, Surabaya \\ ${ }^{2}$ Badan Karantina Ikan, Pengendalian Mutu dan Keamanan Hasil Perikanan Surabaya, Surabaya \\ ${ }^{1}$ Fakultas Teknologi Pertanian, Universitas Brawijaya, Malang \\ *wahyu.isroni@fpk.unair.ac.id
}

\begin{abstract}
Abstrak
Ikan lele (C. gariepinus) merupakan jenis ikan konsumsi budidaya yang dapat dilakukan pada lahan sempit dan air terbatas pada padat tebar tinggi. Perlakuan yang digunakan adalah padat penebaran berbeda $\left(100 \mathrm{ekor} / \mathrm{m}^{3}\right.$, $300 \mathrm{ekor} / \mathrm{m}^{3}$, dan 500 ekor $/ \mathrm{m}^{3}$ ) untuk mengetahui komunitas bakteri pada kepadatan berbeda. Pada kolam 1 hari pertama menunjukkan kepadatan $5.7 \times 10^{4} \mathrm{CFU} / \mathrm{ml}$, spesies yang ditemukan yaitu Bacillus subtilis dan Bacillus megaterium. Pada kolam 1 hari ke-30 menunjukkan kepadatan $8.3 \times 10^{4} \mathrm{CFU} / \mathrm{ml}$, spesies yang ditemukan yaitu Bacillus subtilis. Pada kolam 1 hari ke-60 menunjukkan kepadatan 3.1x10 $\mathrm{CFU} / \mathrm{ml}$, spesies yang ditemukan yaitu Empedobacter brevis. Pada kolam 2 hari pertama menunjukkan kepadatan $3.2 \times 10^{3} \mathrm{CFU} / \mathrm{ml}$, spesies yang ditemukan yaitu Bacillus subtilis. Pada kolam 2 hari ke-30 menunjukkan kepadatan $3.5 \times 10^{3} \mathrm{CFU} / \mathrm{ml}$, spesies yang ditemukan yaitu Spingomonas paucimobilis. Pada kolam 2 hari ke-60 menunjukkan kepadatan 3.7x10 $\mathrm{CFU} / \mathrm{ml}$, spesies yang ditemukan yaitu Empedobacter brevis. Pada kolam 3 hari pertama menunjukkan kepadatan 1.4x10 3 CFU/ml, spesies yang ditemukan yaitu Staphilococus vitulus dan Bacillus megaterium. Pada kolam 3 hari ke-30 menunjukkan kepadatan $1.7 \times 10^{3} \mathrm{CFU} / \mathrm{ml}$, spesies yang ditemukan yaitu Stapilococus xylosus dan Bacillus cereus. Pada kolam 3 hari ke-60 menunjukkan kepadatan 3.6x10 $\mathrm{CFU} / \mathrm{ml}$, spesies yang ditemukan yaitu Bacillus subtilis dan Bacillus lincheniformis.
\end{abstract}

Kata kunci: C. Gariepinus, Bacillus subtili, Bacillus megaterium, Bacillus lincheniformis

\begin{abstract}
Catfish (C. gariepinus) is a type of consumption fish that is starting to grab the attention of aquaculture entrepreneurs because it can be done on a narrow land and limited amount of water with high stocking densities. The method used in this research is a descriptive method which is a research conducted to provide an objective picture. The treatments used are different stocking densities $\left(100 \mathrm{fish} / \mathrm{m}^{3}, 300 \mathrm{fish} / \mathrm{m} 3\right.$, and $\left.500 \mathrm{fish} / \mathrm{m}^{3}\right)$ to determine the bacterial community at different frequencies. Water samples were taken three times during the maintenance period, namely the $1^{\text {st }}$ day, $30^{\text {th }}$ day, and $60^{\text {th }}$ day. Water quality parameter is measured every morning and evening for 60 days. There are three components in the recirculation system used, namely, fish rearing ponds, swirl-filter tanks, and biofilter tanks. The first pond showed an initial density of $5.7 \times 10^{4} \mathrm{CFU} / \mathrm{ml}$, with Bacillus subtilis and Bacillus megaterium. After 30 days, there are Bacillus subtilis with $8.3 \times 10^{4} \mathrm{CFU} / \mathrm{ml}$ density. In day 60, there are Empedobacter brevis $\left(3.1 \times 10^{4} \mathrm{CFU} / \mathrm{ml}\right)$. For the second pond, the initial Bacillus subtilis density is $3.2 \times 10^{3} \mathrm{CFU} / \mathrm{ml}$. On day 30 , the density is $3.5 \times 10^{3} \mathrm{CFU} / \mathrm{ml}$, the species found was Spingomonas paucimobilis. On day 60, the Empedobacter brevis density is $3.7 \times 10^{5} \mathrm{CFU} / \mathrm{ml}$. In the third pond, the initial mass is $1.4 \times 10^{3}$ $\mathrm{CFU} / \mathrm{ml}$ of Staphilococus vitulus and Bacillus megaterium. After 30 days the density is $1.7 \times 10^{3} \mathrm{CFU} / \mathrm{ml}$ (Stapilococus xylosus and Bacillus cereus). The $60^{\text {th }}$ day showed a density of $3.6 \times 10^{5} \mathrm{CFU} / \mathrm{ml}$ of Bacillus subtilis and Bacillus lincheniformis.
\end{abstract}

Keywords : C. Gariepinus, Bacillus subtili, Bacillus megaterium, Bacillus lincheniformis

\section{PENDAHULUAN}

Sumber daya alam seperti air dan lahan, menjadikan intensifikasi sebagai pilihan yang paling memungkinkan dalam meningkatkan produksi budidaya. Upaya untuk mengembangkan perikanan budidaya terutama pada sistem intensif hingga kini masih terus dilakukan mengingat sistem tersebut masih terkendala oleh berbagai masalah di antara buangan limbah akuakultur. Teknologi water system recirculation merupakan salah satu alternatif dalam mengatasi masalah kualitas 
air dalam akuakultur (Rachmawati et al., 2015).

$\begin{array}{crr}\text { Sistem } & \text { resirkulasi } & \text { akuakultur } \\ \text { (Recirculation } & \text { Aquaculture } & \text { System) }\end{array}$ merupakan sistem yang memanfaatkan ulang air yang telah digunakan dengan resirkulasi melewati sebuah filter, sehingga sistem ini bersifat hemat air. Filter di dalam sistem ini berfungsi mekanis untuk menjernihkan air dan berfungsi biologis untuk menetralisasi sewa amonia yang toksik menjadi sewa nitrat yang kurang toksik dalam suatu proses yang disebut nitrifikasi. Berhasil tidak budidaya ikan di dalam sistem resirkulasi sangat ditentukan oleh baik tidak fungsi nitrifikasi di dalam sistem tersebut (Samsundari dan Wirawan, 2013; Prayogi et al., 2019).

Kesuksesan sistem resirkulasi tergantung pada efektivitas sistem dalam menangani atau mengolah limbah budidaya terutama yang berupa limbah organik. Proses pengolahan limbah pada sistem resirkulasi dapat berupa filtrasi fisik, filtrasi biologi dan filtrasi kimia. Dalam sistem resirkulasi proses filtrasi biologi merupakan hal yang paling penting. Bakteri berperan sebagai agen pengendali biologi yaitu dapat memperbaiki kualitas air melalui pendegradasian bahan organik. Bakteri sebagai pengendali hayati bersifat sangat spesifik (Prayogo et al., 2012) dengan demikian perlu dianalisis peranan bakteri pendegradasi bahan organik. Hasil analisis bakteri tersebut merupakan spesies bakteri indigenos yang dapat digunakan untuk memperbaiki kualitas air melalui pendegradasian bahan organik pada budidaya lele dumbo (C. gariepinus) pada sistem resirkulasi.

\section{METODOLOGI}

\section{Waktu dan Tempat}

Penelitian dilaksanakan pada Desember 2018 - Januari 2019 di Desa Sumurgung, Kecamatan Tuban Kabupaten Tuban - Jawa Timur dan Laboratorium Penguji UPT Pengembangan Budidaya Air Payau Dinas Kelautan dan Perikanan Jawa Timur, Bangil, Pasuruan.

\section{Materi Penelitian}

Materi yang digunakan adalah materi untuk perhitungan jumlah sel bakteri, Isolasi bakteri dan pewarnaan gram. Parameter lingkungan yang diukur dalam penelitian ini adalah suhu, oksigen terlarut $\mathrm{DO}, \mathrm{pH}$, dan amonia.

\section{Rancangan Penelitian}

Penelitian analisis komunitas bakteri di bioball pada budidaya lele dumbo ( $C$. gariepinus) sistem resirkulasi menggunakan 3 unit resirkulasi. Penelitian ini dilaksanakan selama 60 hari.

\section{Prosedur Kerja}

Kolam terpal bundar dengan diameter $1 \mathrm{~m}$ dan ketinggian kolam $1 \mathrm{~m}$ sebagai wadah budidaya. Filter yang digunakan adalah dengan swirl filter dan filter biologi dengan bioball filter. Jumlah bioball di dalam bak filter 628 buah per unit. Pada outlet wadah budidaya dipasang stop kran untuk menahan laju air sampai air di wadah budidaya. Air dari outlet dihubungkan menggunakan pipa PVC 1,5" ke swirl filter, kemudian dari swirl filter dihubungkan dengan pipa PVC 1" ke bioball filter. Air dari bioball filter dialirkan kembali ke wadah budidaya dengan bantuan airlift system.

\section{Pengamatan Morfologi Koloni Bakteri}

Pengamatan morfologi yaitu dengan mengamati bentuk, susunan dan warna suatu koloni dari isolat bakteri. Menurut Dwidjoseputro (2005), morfologi koloni bakteri yang tumbuh di permukaan media memiliki sifat-sifat umum yaitu besar kecil koloni seperti titik atau bahkan melebar sampai menutup permukaan media, bentuk koloni seperti bulat atau memanjang, tepi koloni rata atau tidak rata, kenaikan permukaan timbul atau rata dengan permukaan medium dan halus-kasar permukaan.

Pengamatan morfologi koloni bakteri dilakukan secara langsung menggunakan alat bantu loop pada isolat bakteri yang telah diinkubasi pada suhu $32^{\circ} \mathrm{C}$ selama 24 
jam. Pengamatan morfologi dilakukan secara aseptik untuk mencegah terjadi kontaminasi.

\section{Pengamatan Isolat Mikroskopis}

Setelah dilakukan pengamatan mikroskopis didapatkan hasil yaitu terdapat 2 jenis bakteri yang menunjukkan gram negatif dan terdapat 10 jenis bakteri yang menunjukkan gram positif. Bakteri pada tiap isolat menunjukkan hasil bentuk bakteri yaitu bacilli (basil/batang) dan Cocci (kokus/bulat).

Menurut pernyataan dari Sardiani et al. (2015), jika dilihat di bawah mikroskop, bakteri gram positif akan berwarna ungu sedangkan bakteri gram negatif akan berwarna merah. Perbedaan reaksi kedua golongan bakteri tersebut terhadap pewarnaan gram disebabkan bakteri gram positif memiliki dinding sel yang lebih tebal yang terdiri dari peptidoglikan dan asam teikoat dibandingkan dengan bakteri gram negatif yang mengandung sedikit peptidoglikan dan bak lipid.

\section{Analisis Data}

Data yang telah dikumpulkan dari penelitian ini dianalisis secara deskriptif.

\section{HASIL DAN PEMBAHASAN Kepadatan Bakteri}

Penelitian analisis komunitas bakteri di kolam pada budidaya lele dumbo ( $C$. gariepinus) sistem resirkulasi, perhitungan jumlah koloni bakteri dilakukan dengan metode hitung cawan (Total Plate Count). Hasil perhitungan jumlah koloni dapat dilihat pada Tabel 1.

Tabel 1. Hasil perhitungan jumlah koloni (CFU/ml).

\begin{tabular}{llllll}
\hline No & Kolam & Hari ke- & \multicolumn{1}{r}{ Kode Sampel } & Kode Uji & Total Bakteri (CFU/ml) \\
\hline 1 & & 0 & K1H0 Air Kolam & 186 & $5.7 \times 10^{3}$ \\
2 & 1 & 30 & K1H30 Air Kolam & 189 & $8.3 \times 10^{3}$ \\
3 & & 60 & K1H60 Air Kolam & 191 & $3.1 \times 10^{3}$ \\
4 & & 0 & K2H0 Air Kolam & 192 & $3.2 \times 10^{3}$ \\
5 & 2 & 30 & K2H30 Air Kolam & 195 & $3.5 \times 10^{3}$ \\
6 & & 60 & K2H60 Air Kolam & 197 & $3.7 \times 10^{3}$ \\
7 & & 0 & K3H0 Air Kolam & 198 & $1.4 \times 10^{3}$ \\
8 & 3 & 30 & K3H30 Air Kolam & 201 & $1.7 \times 10^{3}$ \\
9 & & 60 & K3H60 Air Kolam & 203 & $3.6 \times 10^{3}$ \\
\hline
\end{tabular}

Tabel di atas, pada kolam 1 di hari ke0 hingga hari ke-30 menunjukkan kenaikan jumlah kepadatan. akan tetapi pada hari ke60 terjadi penurunan jumlah koloni. Jumlah koloni bakteri pada awal hingga akhir pemeliharaan di kolam 2 dan 3 jumlah koloni bakteri menunjukkan peningkatan jumlah di setiap waktu pengambilan sampel karena pertumbuhan bakteri selama penelitian

\section{Pengamatan Morfologi Koloni Bakteri}

Bentuk morfologi isolat bakteri meliputi warna koloni, tepian koloni, dan bentuk koloni dapat dilihat pada Tabel 2 . 
Tabel 2. Morfologi koloni bakteri.

\begin{tabular}{|c|c|c|c|c|c|}
\hline \multirow{2}{*}{ No } & \multirow{2}{*}{ Kolam } & \multirow{2}{*}{ Hari Ke- } & \multicolumn{3}{|c|}{ Morfologi Koloni } \\
\hline & & & Bentuk & Tepi & Warna \\
\hline \multirow{2}{*}{1} & \multirow{4}{*}{1} & \multirow{2}{*}{0} & Oval & Tidak rata & Oren \\
\hline & & & Bulat & Rata & Krem \\
\hline 2 & & 30 & Bulat & Tidak rata & Krem \\
\hline 3 & & 60 & Bulat & Rata & Krem \\
\hline 4 & \multirow{3}{*}{2} & 0 & Bulat & Tidak rata & Krem \\
\hline 5 & & 30 & Bulat & Tidak rata & Krem \\
\hline 6 & & 60 & Bulat & Rata & Krem \\
\hline \multirow{2}{*}{7} & \multirow{6}{*}{3} & \multirow{2}{*}{0} & Bulat & Rata & Krem \\
\hline & & & Bulat & Rata & Oren \\
\hline \multirow{2}{*}{8} & & \multirow{2}{*}{30} & Bulat & Tidak rata & Krem \\
\hline & & & Bulat & Rata & Krem \\
\hline \multirow{2}{*}{9} & & \multirow{2}{*}{60} & Bulat & Tidak rata & Oren \\
\hline & & & Oval & Tidak rata & Krem \\
\hline
\end{tabular}

\section{Pengamatan Isolat Mikroskopis}

Pewarnaan gram dan pengamatan bakteri di bawah mikroskop merupakan salah satu pengamatan secara mikroskopis yang termasuk dalam tahapan identifikasi. Pengamatan secara mikroskopis dilakukan untuk mengetahui jenis gram dan bentuk bakteri. Hasil pengamatan pewarnaan gram pada mikroskop dapat dilihat pada. Hasil pengamatan uji gram dan bentuk bakteri dapat dilihat pada Tabel 3.

Tabel 3. Hasil pengamatan mikroskopis uji gram.

\begin{tabular}{|c|c|c|c|c|c|c|c|}
\hline No & Kolam & $\begin{array}{l}\text { Hari } \\
\text { Ke- }\end{array}$ & Kode Sampel & $\begin{array}{l}\text { Kode } \\
\text { Uji }\end{array}$ & $\begin{array}{l}\text { Hasil } \\
\text { Pewarnaan }\end{array}$ & Hasil & $\begin{array}{l}\text { Bentuk } \\
\text { Bakteri }\end{array}$ \\
\hline \multirow{2}{*}{1} & \multirow{4}{*}{1} & \multirow{2}{*}{0} & K1H0 Air & $186 a$ & Ungu & Positif & Bacilli \\
\hline & & & Kolam & $186 b$ & Ungu & Positif & Bacilli \\
\hline 2 & & 30 & $\begin{array}{l}\text { K1H30 Air } \\
\text { Kolam }\end{array}$ & 189 & Ungu & Positif & Bacilli \\
\hline 3 & & 60 & $\begin{array}{l}\text { K1H60 Air } \\
\text { Kolam }\end{array}$ & 191 & Merah & Negatif & Bacilli \\
\hline 4 & & 0 & $\begin{array}{l}\text { K2H0 Air } \\
\text { Kolam }\end{array}$ & 192 & Ungu & Positif & Bacilli \\
\hline 5 & 2 & 30 & $\begin{array}{l}\text { K2H30 Air } \\
\text { Kolam }\end{array}$ & 195 & Merah & Negatif & Bacilli \\
\hline 6 & & 60 & $\begin{array}{l}\text { K2H60 Air } \\
\text { Kolam }\end{array}$ & 197 & Merah & Negatif & Bacilli \\
\hline \multirow{2}{*}{7} & \multirow{6}{*}{3} & \multirow{2}{*}{0} & K3H0 Air & $198 \mathrm{a}$ & Ungu & Positif & Cocci \\
\hline & & & Kolam & $198 b$ & Ungu & Positif & Bacilli \\
\hline \multirow{2}{*}{8} & & \multirow{2}{*}{30} & K3H30 Air & $201 \mathrm{a}$ & Ungu & Positif & Cocci \\
\hline & & & Kolam & $201 b$ & Ungu & Positif & Bacilli \\
\hline \multirow{2}{*}{9} & & \multirow{2}{*}{60} & K3H60 Air & $203 a$ & Ungu & Positif & Bacilli \\
\hline & & & Kolam & $203 b$ & Ungu & Positif & Bacilli \\
\hline
\end{tabular}

Setelah didapatkan hasil pengamatan mikroskopis selanjutnya dilakukan uji biokimia yang bertujuan untuk mengetahui jenis-jenis bakteri yang teridentifikasi pada saat penelitian. Uji biokimia dapat mengetahui karakteristik bakteri dalam mereduksi unsur glukosa, protein, dan urea. 
Adapun bakteri yang teridentifikasi dapat dilihat pada Tabel 4. Pada uji biokimia ditemukan beberapa bakteri yang merupakan bakteri patogen, akan tetapi bakteri yang mendukung keberlangsungan ekosistem masih mendominasi merupakan bakteri nitrifikasi.

Tabel 4. Hasil identifikasi bakteri.

\begin{tabular}{|c|c|c|c|c|c|}
\hline No & Kolam & $\begin{array}{l}\text { Hari } \\
\text { Ke- }\end{array}$ & Kode Sampel & Kode Uji & Spesies Bakteri \\
\hline & \multirow{4}{*}{1} & & & $186 a$ & Bacillus subtilis \\
\hline 1 & & 0 & K1H0 Air Kolam & $186 b$ & Bacillus megaterium \\
\hline 2 & & 30 & K1H30 Air Kolam & 189 & Bacillus subtilis \\
\hline 3 & & 60 & K1H60 Air Kolam & 191 & Empedobacter brevis \\
\hline 4 & \multirow{3}{*}{2} & 0 & K2H0 Air Kolam & 192 & Bacillus subtilis \\
\hline 5 & & 30 & K2H30 Air Kolam & 195 & Sphingomonas paucimobilis \\
\hline 6 & & 60 & K2H60 Air Kolam & 197 & Empedobacter brevis \\
\hline 7 & & 0 & K3H0 Air Kolam & $\begin{array}{l}198 \mathrm{a} \\
198 \mathrm{~b}\end{array}$ & $\begin{array}{l}\text { Staphilococus vitulus } \\
\text { Bacillus magetarium }\end{array}$ \\
\hline 8 & 3 & 30 & K3H30 Air Kolam & $\begin{array}{l}201 \mathrm{a} \\
201 \mathrm{~b}\end{array}$ & $\begin{array}{l}\text { Staphilococus xylosus } \\
\text { Bacillus cereus }\end{array}$ \\
\hline 9 & & 60 & K3H60 Air Kolam & $\begin{array}{l}203 a \\
203 b\end{array}$ & $\begin{array}{l}\text { Bacillus subtilis } \\
\text { Bacillus licheniformis }\end{array}$ \\
\hline
\end{tabular}

\section{Parameter Penunjang Kualitas Air}

Penelitian ini didapatkan hasil nilai rata-rata pada masing-masing parameter kualitas air (suhu, DO, pH, amonia, nitrat), antara lain: pengukuran suhu pada penelitian ini dilakukan dua kali sehari selama 60 hari yaitu pada waktu pagi hari dan sore hari. Pengukuran suhu dilakukan di kolam pemeliharaan, swirl filter dan bioball filter dengan tujuan untuk mengetahui perbedaan fluktuasi suhu di ketiga wadah dalam satu unit resirkulasi. menunjukkan bahwa rata-rata suhu di kolam pemeliharaan selama penelitian antara $28,7-29,6^{\circ} \mathrm{C}$.

Suhu rata-rata pada pagi hari di kolam 1 yaitu $28,7^{\circ} \mathrm{C}$, di kolam 2 yaitu $28,9^{\circ} \mathrm{C}$ dan di kolam 3 yaitu $28,9^{\circ} \mathrm{C}$. Suhu rata-rata pada sore hari di kolam 1 yaitu $29,3^{\circ} \mathrm{C}$, di kolam 2 yaitu $29,5^{\circ} \mathrm{C}$ dan di kolam 3 yaitu $29,6^{\circ} \mathrm{C}$. Jika dilihat perbedaan suhu pada pagi hari dan sore hari maka lebih tinggi suhu pada sore hari. Hal ini dikarenakan pengukuran suhu di pagi hari dilakukan sebelum ada-sinar matahari dan pengukuran suhu di sore hari masih terpapar sinar matahari sehingga menyebabkan suhu di perairan meningkat.
Pengukuran oksigen terlarut pada penelitian ini menunjukkan bahwa rata-rata oksigen terlarut di kolam pemeliharaan selama penelitian antara 4,3 - 4,8 mg/l. Oksigen terlarut rata-rata pada pagi hari di kolam 1 yaitu 4,6 mg/l, di kolam 2 yaitu 4,6 $\mathrm{mg} / \mathrm{L}$ dan di kolam 3 yaitu $4,7 \mathrm{mg} / \mathrm{L}$. Oksigen terlarut rata-rata pada sore hari di kolam 1 yaitu 4,8 mg/L, di kolam 2 yaitu 4,4 $\mathrm{mg} / \mathrm{L}$ dan di kolam 3 yaitu 4,3 mg/L. Dan untuk pengukuran $\mathrm{pH}$ menunjukkan bahwa rata-rata $\mathrm{pH}$ di kolam pemeliharaan selama penelitian yaitu 7,6 . Nilai $\mathrm{pH}$ rata-rata pada pagi hari di kolam 1 yaitu 7,6, di kolam 2 yaitu 7,6 dan di kolam 3 yaitu 7,6. pH ratarata pada sore hari di kolam 1 yaitu 7,6, di kolam 2 yaitu 7,6 dan di kolam 3 yaitu 7,6.

Pengambilan sampel air untuk pengukuran amonia dilakukan pada hari ke $0,15,30,45$ dan 60. Pengukuran amonia dilakukan di kolam pemeliharaan, swirl filter dan bioball filter dengan tujuan untuk mengetahui perbedaan fluktuasi amonia di ketiga wadah dalam satu unit resirkulasi. Hasil pengukuran amonia diperoleh grafik yang dapat dilihat pada Gambar 1. 


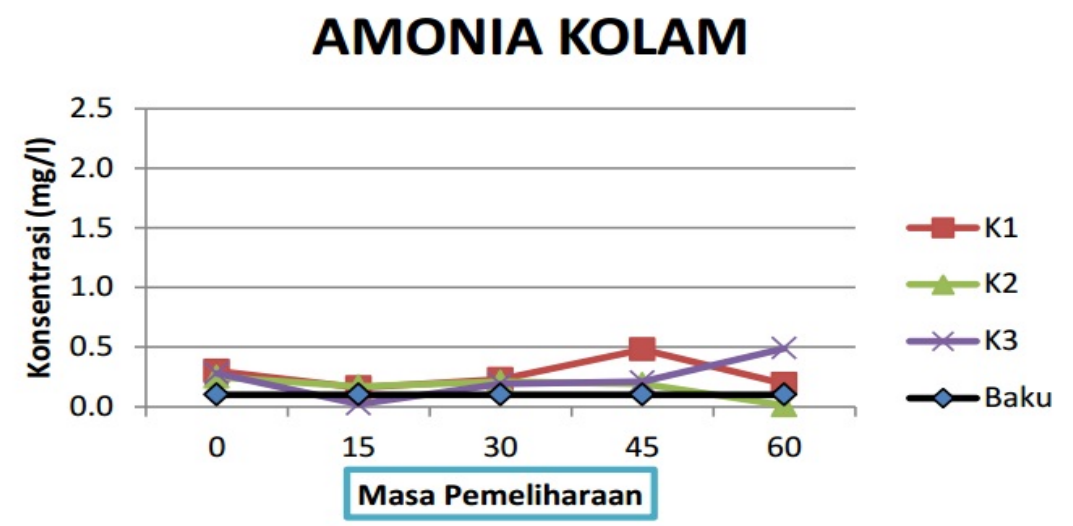

Gambar 1. Grafik fluktuasi amonia di kolam pemeliharaan.
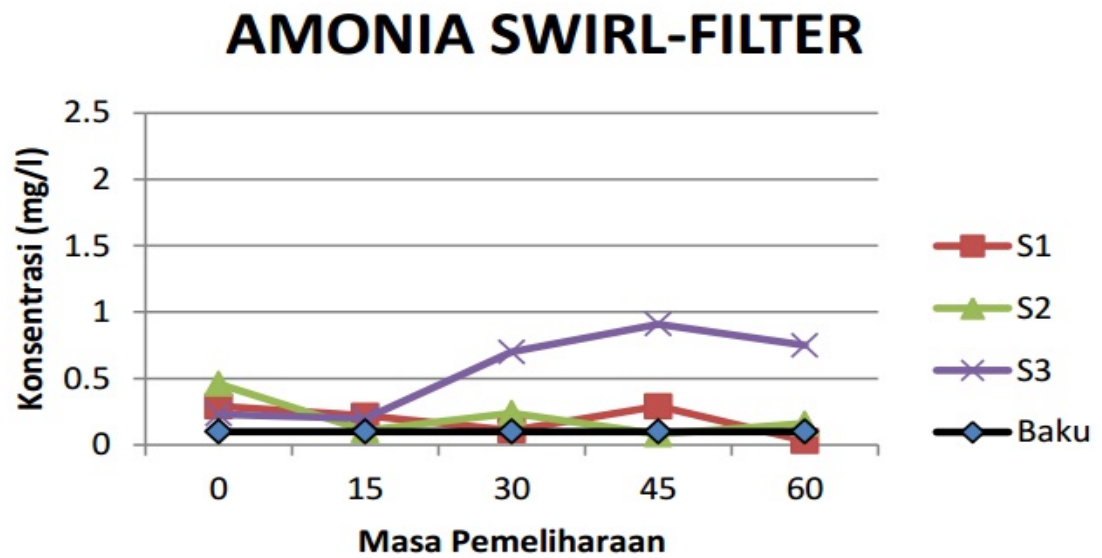

Gambar 2. Grafik fluktuasi amonia di swirl filter.

Gambar 2 diketahui konsentrasi amonia yang berada di kolam penelitian, swirl filter dan bioball filter selama 60 hari masa pemeliharaan. Konsentrasi amonia pada kolam penelitian 1 terendah sebesar $0,16 \mathrm{mg} / \mathrm{l}$ dan tertinggi $0,48 \mathrm{mg} / \mathrm{l}$, pada kolam penelitian 2 konsentrasi amonia terendah sebesar $0,01 \mathrm{mg} / 1$ dan tertinggi sebesar $0,25 \mathrm{mg} / \mathrm{l}$ dan konsentrasi amonia pada kolam penelitian 3 terendah sebesar $0,02 \mathrm{mg} / 1$ dan tertinggi sebesar $0,49 \mathrm{mg} / \mathrm{l}$. Konsentrasi amonia pada swirl filter 1 terendah sebesar $0,03 \mathrm{mg} / \mathrm{l}$ dan tertinggi sebesar $0,29 \mathrm{mg} / \mathrm{l}$, pada swirl filter 2 konsentrasi amonia terendah sebesar 0,08 dan tertinggi $0,46 \mathrm{mg} / \mathrm{l}$ dan pada swirl filter 3 konsentrasi amonia terendah sebesar 0,2 dan tertinggi sebesar $0,91 \mathrm{mg} / \mathrm{l}$. Kemudian konsentrasi amonia pada bioball filter 1 terendah sebesar $0,18 \mathrm{mg} / \mathrm{l}$ dan tertinggi sebesar 0,28 mg/l, pada bioball filter 2 konsentrasi amonia terendah sebesar 0,03 $\mathrm{mg} / \mathrm{l}$ dan tertinggi sebesar $0,3 \mathrm{mg} / \mathrm{l}$ dan pada bioball filter 3 konsentrasi amonia terendah sebesar $0,08 \mathrm{mg} / \mathrm{l}$ dan tertinggi sebesar 0,37 $\mathrm{mg} / \mathrm{l}$.

Nilai amonia pada kolam 3 menunjukkan nilai tertinggi Hal ini disebabkan karena padat tebar yang tinggi sehingga berimplikasi pada tinggi-bahan organik. Akan tetapi disisi lain hal ini sangat baik untuk pertumbuhan bakteri. Terbukti bahwa kepadatan bakteri tertinggi ada pada kolam 3 dan bakteri nitrifikasi bak ditemukan juga pada kolam 3 . 
AMONIA BIOBALL

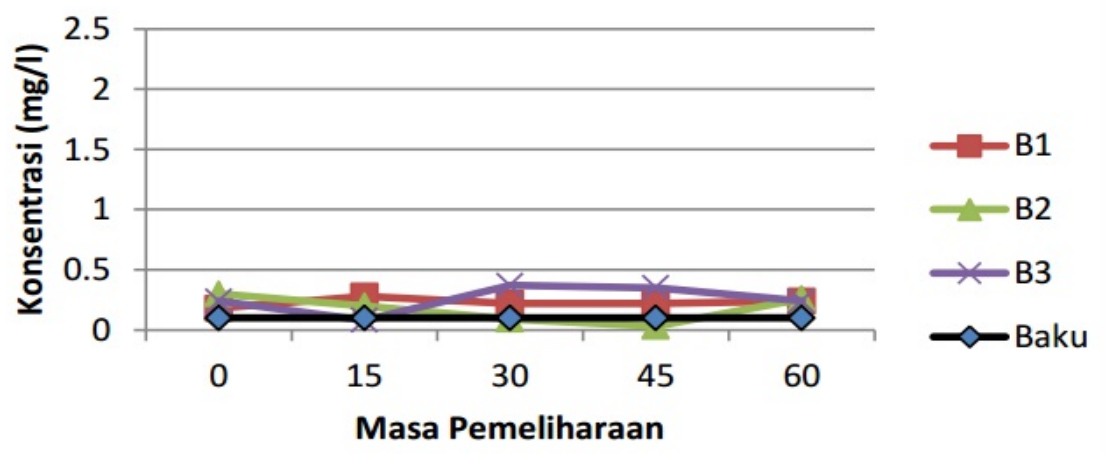

Gambar 3. Grafik fluktuasi amonia di bioball filter.

Gambar 3 menunjukkan bahwa ratarata amonia di kolam pemeliharaan selama penelitian antara $0,17-0,60 \mathrm{mg} / \mathrm{l}$. Nilai amonia rata-rata di kolam 1 yaitu $0,27 \mathrm{mg} / \mathrm{l}$, di kolam 2 yaitu $0,17 \mathrm{mg} / \mathrm{l}$ dan di kolam 3 yaitu $0,60 \mathrm{mg} / \mathrm{l}$. Nilai amonia selama penelitian masih dalam kisaran yang tidak berbahaya bagi kelangsungan hidup ikan lele dumbo (C. gariepinus).

Hal ini sesuai dengan penelitian Makmur dan Fahrur (2011), amonia bebas yang tidak terionisasi bersifat toksik terhadap hewan akuatik. Toksisitas amonia terhadap organisme akuatik akan meningkat jika terjadi penurunan kadar oksigen terlarut, $\mathrm{pH}$ dan suhu. Kadar amonia yang rendah yaitu $<2 \mathrm{mg} / \mathrm{l}$ pada suatu perairan sangat baik untuk kehidupan biota budidaya. Menurut Pelczar et al. (2005), apabila bakteri Nitrosomonas mulai tumbuh secara perlahan amonia menurun karena amonia mulai dikonsumsi oleh bakteri Nitrosomonas.

\section{KESIMPULAN DAN SARAN \\ Kesimpulan}

Spesies yang ditemukan pada kolam 1 yaitu Bacillus subtilis, Bacillus megaterium, Bacillus subtilis, dan Empedobacter brevis. Pada kolam 2 spesies yang ditemukan yaitu Bacillus subtilis, Spingomonas paucimobilis, dan Empedobacter brevis. Pada kolam 3 spesies yang ditemukan yaitu Staphilococus vitulus, Bacillus megaterium, Stapilococus xylosus, Bacillus cereus, Bacillus subtilis, dan Bacillus lincheniformis.

\section{Saran}

Perlu dilakukan penelitian lanjutan mengenai spesies bakteri yang ada pada sistem resirkulasi budidaya lele dumbo.

\section{DAFTAR PUSTAKA}

Dwidjoseputro, D., 2005. Dasar-Dasar Mikrobiologi. Penerbit Djambatan. Jakarta. pp. 206.

Makmur, R. dan Fahrur, M., 2011. Hubungan antara kualitas air dan plankton di tambak Kabupaten Tanjung Jabung Barat Provinsi Jambi. In Prosiding Forum Inovasi Teknologi Akuakultur, pp. 961-968.

Pelczar, M.J., Chan, E.C.S., Krieg, N.R., Edwards, D.D. and Pelczar, M.F., 1993. Microbiology: concepts and applications (Vol. 182). New York: McGraw-Hill.

Prayogi, Y.T., Kusdarwati, R. dan Kismiyati, K., 2019. Isolasi, identifikasi dan presentasi ikan lele dumbo (Clarias gariepinus) yang terinfeksi bakteri aeromonas hydrophila yang dipelihara di keramba jaring apung di Bozem Moro Krembangan, Surabaya. Journal of Aquaculture and Fish Health, 5(2), pp. 64-69.

Prayogo, Rahardja, B.S. dan Manan, A., 2012. Eksplorasi bakteri indigen pada pembenihan ikan lele dumbo (Clarias 
sp.) sistem resirkulasi tertutup. Jurnal Ilmiah Perikanan dan Kelautan, 4(2), pp. 193-198.

Rachmawati, D., Samidjan, I. dan Setyono, H., 2015. Manajemen kualitas air media budidaya ikan lele sangkuriang (Clarias gariepinus) dengan teknik probiotik pada kolam terpal di Desa Vokasi Reksosari, Kecamatan Suruh, Kabupaten Semarang. PENA Akuatika: Jurnal Ilmiah Perikanan dan Kelautan, 12(1), pp. 24 - 32.

Samsundari, S. dan Wirawan, G.A., 2013. Analisis penerapan biofilter dalam sistem resirkulasi terhadap mutu kualitas air budidaya ikan sidat (Anguilla bicolor). Jurnal Gamma, 8(2), pp. $86-97$.

Sardiani, N., Litaay, M., Budji, R.G., Priosambodo, D., Syahribulan dan Dwyana, Z., 2015. Potensi tunikata Rhopalaea sp. sebagai sumber inokulum bakteri endosimbion penghasil antibakteri. Jurnal Alam dan Lingkungan, 6(11), pp. 1-10. 